\title{
Influence of wheat supplementation on intake and digestibility in dairy cows fed autumn grass ad libitum indoors
}

\author{
R Delagarde, JL Peyraud \\ INRA, Station de Recherches sur la Vache Laitiere, 35590 Saint Gilles, France
}

The supplementation of fresh grass with a significant amount of rapidly fermentable cereal $(6 \mathrm{~kg}$ : Arriaga-Jordan and Holmes, 1986, J Agric Sci, Camb, 106, 581-592) reduces herbage intake and digestibility. The aim of this study was to determine the effect of lower levels of supplement (wheat) on intake and digestibility in dairy cows fed on a herbage-based diet.

A 'control' diet (C) comprising only fresh perennial ryegrass was compared to a 'supplemented' diet (S) comprising the same fresh grass plus $3 \mathrm{~kg}$ of pelleted wheat. Three ruminally cannulated Holstein cows $(632 \mathrm{~kg}$ live weight) in mid-lactation were used in an incomplete switchback design during 3 periods of 12 days, in October and November 1993. Cows were stall fed with grass ad libitum 3 meals per day at $7.30 \mathrm{am}, 2 \mathrm{pm}$ and $9.30 \mathrm{pm}$. Cows on the $S$ diet were given concentrate before grass at $7.00 \mathrm{am}$ and $9.00 \mathrm{pm}(1.5 \mathrm{~kg}$ each time). Grass was cut once daily and stored at $+4^{\circ} \mathrm{C}$ until meal times. Herbage intake was recorded for each period from day 7 to day 11 , and digestibility measured from day 8 to day 12 by total faecal collection. Urine was collected with harnesses. On day 10 of the two first periods, the $\mathrm{pH}, \mathrm{NH}_{3}$ and VFA contents of the ruminal fluid and blood urea were measured 13 times throughout the day, i.e. at $12 \mathrm{pm}, 4$ am and every $90 \mathrm{~min}$ from 7 am to $10 \mathrm{pm}$.

The mean chemical composition of the grass (per $\mathrm{kg} \mathrm{DM}$ ) was as follows : $878 \mathrm{~g} \mathrm{OM}, 223 \mathrm{~g}$ $\mathrm{CP}$ and $463 \mathrm{~g}$ NDF. Cows on the $S$ diet showed both higher total OM intake (15.0 vs $14.5 \mathrm{~kg} / \mathrm{d}, \mathrm{P}<0.05)$ and higher milk production (21.1 vs $20.0 \mathrm{~kg} \mathrm{FCM}, P<0.03$ ) than cows on the $\mathrm{C}$ diet, but milk fat content $(39.3 \mathrm{~g} / \mathrm{kg})$ and protein content $(31.7 \mathrm{~g} / \mathrm{kg})$ were not affected by supplementation. Herbage OM intake was greatly depressed by supplementation (12.4 and $14.5 \mathrm{~kg} O M$ for the $S$ and $C$ diets respectively, $P<0.001)$. This high substitution rate $(0.80 \mathrm{~kg}$ per $\mathrm{kg}$ OM concentrate) is probably due to the positive energy balance $(+1.1$ and $1.4 \mathrm{UFL} / \mathrm{d}$ for the $\mathrm{S}$ and $\mathrm{C}$ diets respectively ; Faverdin et al, 1991, Livest Prod Sci, 27, 137-156). The organic matter digestibility (OMD) of the whole diet was higher for the $S$ than for the $C$ diet $(0.832$ vs $0.815, \mathrm{P}<0.05$ ). For the $\mathrm{S}$ diet, herbage $\mathrm{OMD}$ was estimated by subtracting the indigestible wheat $O M$ from total feacal output, assuming that wheat OMD is 0.89 (INRA, 1989, Ruminant Nutrition (ed R Jarrige), London, Paris, John Libbey). In these conditions, supplementation had no effect on herbage OMD $(0.821$ and 0.815 for the $S$ and $C$ diets respectively, $\mathrm{P}>0.20$ ). Neither the mean $\mathrm{pH}$ (5.9), the total acidity ( $138 \mathrm{mmoles} / \mathrm{l}$ ), the acetate $(62.1 \%)$, propionate $(21.6 \%)$ and butyrate $(10.7 \%)$ contents in the ruminal VFA, nor the postprandial dynamics of ruminal fermentations were affected by supplementation. These results support the absence of variation in herbage $O M$ digestibility and in milk fat content when wheat was given. Feeding concentrate had little effect on $\mathrm{N}$ metabolism since ruminal ammonia (290 mg/l), uremia $(45 \mathrm{mg} / 100 \mathrm{ml}$ ) and urine $\mathrm{N}$ output $(280 \mathrm{~g} / \mathrm{d})$ were not statistically different between diets.

Despite a high substitution rate, no digestive interaction is expected in high-quality pastures with a moderate amount of a rapidly fermentable cereal supplement. 